\title{
PELECEHAN SEKSUAL DI INSTITUSI PENDIDIKAN: SEBUAH PERSPEKTIF KEBIJAKAN
}

\author{
Deding Ishak \\ STAI YAPATA Al-Jawami, Bandung \\ Email: dedingishak@yahoo.com
}

\begin{abstract}
Abstrak
Pelecehan seksual diidentifikasi sebagai masalah kesehatan masyarakat yang besar dan tersembunyi di sebagian besar institusi/organisasi. Pelecehan seksual sering kali menjadi permasalahan yang tersembunyi karena korban biasanya enggan untuk melaporkan pengalamannya. Dengan menggunakan data berdasarkan hasil wawancara dan survei, penelitian ini mengeksplorasi efek gender, ras/etnis, orientasi seksual, usia saat pendaftaran, status siswa, dan waktu yang dihabiskan di institusi terhadap risiko siswa untuk korban pelecehan seksual yang dilakukan oleh rekan dan fakultas/staf, serta sejauh mana viktimisasi bagi siswa yang mengalami pelecehan. Hasil penelitian kemudian menemukan bahwa waktu di institusi terbukti meningkatkan risiko dan tingkat viktimisasi dari pelecehan. Kemudian mahasiswa sarjana tradisional, mahasiswi, dan mahasiswa minoritas gender dan seksual ditemukan pada peningkatan risiko pelecehan. Menjadi perempuan meningkatkan kemungkinan mengalami pelecehan seksual oleh dosen/staf dan teman sebaya. Para mahasiswa/I yang memiliki minoritas ras dilaporkan lebih sedikit pelecehan seksual, namun akan mengalami tekanan yang cukup tinggi dari pihak pelaku dan masyarakat sekitar jika melakukan pelaporan. Penelitian ini diharapkan dapat menemukan cara untuk menciptakan kebijakan terhadap kasus kekerasan dan pelecehan seksual dalam institusi pendidikan.
\end{abstract}

Kata Kunci: Pelecehan Seksual, Kekerasan Seksual, Pendidikan, Kebijakan.

\begin{abstract}
Sexual harassment is identified as a major and hidden public health problem in most institutions/organizations. Sexual harassment is often a hidden problem because victims are usually reluctant to report their experiences. Using data based on interviews and surveys, this study explores the effects of gender, racelethnicity, sexual orientation, age at enrollment, student status, and time spent at the institution on students' risk of being victims of sexual harassment by peers and faculty/staff, as well as the extent of victimization of students who experience harassment. Then traditional undergraduate students, college students, and gender and sexual minority students were found to be at increased risk of harassment. Being female increases the chances of being sexually harassed by lecturers/staff and peers. Students who have racial minorities reported less sexual harassment, but would experience high pressure from the perpetrators and the surrounding community if they did report. This research is expected to find a way to create policies on cases of violence and sexual harassment in educational institutions.
\end{abstract}

Keywords: Sexual Harassment, Sexual Violence, Education, Policy.

\section{A. PENDAHULUAN}

Pelecehan seksual merupakan bagian dari diskriminasi seksual. Berbagai negara telah membuat peraturan agar tidak lagi terjadi seksisme dan diskriminasi gender dalam dunia 
pendidikan. Namun sayangnya masih banyak sekali laporan mengenai terjadi pelecehan seksual dalam dunia pendidikan, khususnya di perguruan-perguruan tinggi (Sihombing, 2016). Melalui hasil survey sebelumnya, ditemukan bahwa perempuan yang memiliki pendidikan yang lebih tinggi cenderung menerima pelecehan seksual dibandingkan perempuan yang tidak memiliki pendidikan yang terlalu tinggi. Banyak perempuan melaporkan terjadinya pelecehan dalam dunia pendidikan tanpa memandang status, baik itu sebagai murid, staf ataupun bagian dari tenaga pengajar (Andini. 2019).

Banyak mahasiswa/i yang bersekolah di perguruan tinggi mengalami pelecehan seksual selama masa belajarnya di institusi tersebut. Hal ini kemudian dapat mengakibatkan menurunnya kualitas dari kesehatan mental, fisik dan hasil akademik (Reitanza, 2018). Beberapa bukti menunjukkan bahwa banyak mahasiswi yang belum menyelesaikan studinya mengelami pelecehan seksual selama masa bersekolah. Para korban pelecehan seksual ini dapat menerima pelecehan dari berbagai pelaku, seperti teman, staff atau bahkan pengajar dari pihak sekolah (Bahri, 2015). Efek negatif sebagai akibat dari korban pelecehan seksual adalah depresi, post-traumatic stress disorder (PTSD), rasa malu, penggunaan alcohol hingga menggangu proses belajar selama bersekolah. Tentunya sekolah-sekolah yang menjadi tempat pelecehan seksual harus segera melakukan investigasi mengenai insiden pelecehan tersebut serta mengatasi permasalahan yang terjadi (Hikmah, 2017). Ketika perguruan tinggi gagal dalam menangani permasalahan pelecehan seksual, maka trauma yang dialami oleh korban pelecehan akan semakin memburuk dan parah.

Dalam berbagai penelitian yang dilakukan mengenai pelecehan seksual, terdapat adanya perhatian kecil yang diberikan kepada hubungan gender, rasa tau etnis dan orientasi seksual dengan pelecehan seksual. Melalui berbagai bukti dalam dunia pendidikan kampus, hal ini mengindikasikan bahwa identitas yang dimiliki oleh mereka akan mempengaruhi risiko dan hasil dari pelecehan seksual yang akan diterima (Kinasih \& Dugis, 2015). Oleh karena itu peneliti kemudian bertujuan untuk meneliti mengenai perbedaan dari identitas yang dimiliki seperti ras, etnis, jenis kelamin dan orientasi seksual terhadap risiko dari pelecehan seksual yang diterima oleh korban.

\section{B. KAJIAN LITERATUR}

\section{Pendidikan}

Pengertian mengenai pendidikan telah menghantui pikiran para pemikir dan filsuf dari waktu-waktu terdahulu seperti Plato dan Socrates (Digdowiseiso, 2020). Walaupun telah muncul berbagai definisi dan pengertian yang berbeda mengenai arti dari pendidikan, Matheson dan Wells beranggapan bahwa kita tidak akan pernah berhasil memberikan definisi yang benar-benar memuaskan mengenai pendidikan (Parma et al., 2018). Gregory berpendapat bahwa pendidikan dapat diartikan berupa upaya penggunaan otak atau pikiran ketika mencoba memahami sosial, fisik dan budaya (Rahmiana, 2019). Sementara itu Peter menjelaskan bahwa penggunaan kata pendidikan merupakan suatu implikasi ketika manusia mencoba mentransmisikan sesuatu yang dianggap penting atau bermanfaat dengan cara yang dapat diterima secara moral (Lobodally, 2014).

Salah satu kesulitan dalam mendefinisikan pengertian dari pendidikan adalah berubahnya istilah pendidikan sesuai dengan berbagai hal yang berhubungan dengannya. Beberapa ahli mengartikan bahwa istilah "sekolah" merupakan sinonim dengan istilah 
pendidikan, sementara ahli-ahli lainnya berpendapat bahwa hubungan yang terjadi antara belajar dan mengajar merupakan hal yang biasa dan dapat terjadi tanpa memerlukan kondisi khusus, sehingga tidak memerlukan istilah pendidikan (Triana, 2018).

Kemunculan argumen mengenai perbedaan istilah sekolah dan pendidikan kemudian menimbulkan pertanyaan, apakah pendidikan merupakan suatu hasil produk, atau apakah proses yang terjadi di dalam pendidikan merupakan bagian yang terpenting dalam pendidikan itu sendiri. Pertanyaan-pertanyaan mengenai pendidikan ini kemudian menunjukkan bahwa terdapat adanya sedikit konsensus mengenai arti yang paling tepat dalam pendidikan (Efferi, 2014). Tidak hanya istilah pendidikan dapat memiliki banyak sekali arti, namun pencarian kriteria agar istilah pendidikan dapat relevan juga merupakan hal yang cukup sulit untuk diperoleh (Yuhana \& Aminy, 2019).

Suatu pendekatan yang berasal dari Wittgenstein dapat memberikan awal yang baik untuk memahami pengertian dari pendidikan. Wittgenstein berpendapat bahwa sebagian besar istilah memiliki arti tergantung dari asal konteks istilah tersebut digunakan (Wahyudi \& Suyitno, 2018). Sering kali suatu istilah tidak memiliki pengertian yang sama dan pasti dalam berbagai penggunaan, namun istilah memiliki sifat seperti alat di mana dapat berfungsi tergantung dari tujuan penggunaannya (Suharyanto, 2016).

Melalui pendekatan Wittgenstein, kita dapat menemukan banyak jawaban atas pengertian pendidikan, tergantung dari konteks pertanyaan yang diberikan. Melalui pertanyaan tersebut, maka kita memungkinkan untuk menerima berbagai jawaban dan definisi yang berbeda mengenai pendidikan (Amirudin, 2017).

\section{Pelecehan Seksual}

Pelecehan seksual dapat diartikan sebagai suatu perilaku yang merendahkan atau menghina seseorang berdasarkan jenis kelamin dari individu tersebut (Ramadyan, 2010). Perilaku ini kemudian dapat melibatkan pemaksaan dan degradasi seksual, materi atau bahan yang berbau seksual, komentar atau candaan, atau perilaku lainnya yang dirasakan oleh seseorang sebagai akibat dari jenis kelamin mereka sehingga mereka di ejek atau dihina (Reza, 2014).

Pelecehan seksual sendiri pada dasarnya tidak hanya pelecehan yang berbau seksual saja. Berbagai perilaku pelecehan yang terjadi karena korban berasal dari jenis kelamin tertentu juga merupakan bentuk dari pelecehan seksual (Sulandjari, 2017). Beberapa ahli berpendapat bahwa pelecehan sosial terjadi ketika korban direndahkan, diejek, atau dihina sebagai seorang manusia di mata orang lain. Kemudian pelecehan ilegal merupakan tindak pelecehan yang kemudian dapat mempengaruhi pekerjaan seseorang, seperti melakukan intervensi dalam pekerjaan seseorang, atau menciptakan suasana pekerjaan yang mengintimidasi, tidak nyaman dan bersifat ofensif di tempat kerja (Mukhlishotin, 2017).

Pengertian yang luas mengenai pelecehan seksual ini memiliki sifat konsisten, di mana hal ini tidak terbatas kepada perilaku yang hanya berhubungan dengan sifat seksual. Definisi ini sendiri telah disetujui oleh berbagai ahli, seperti para pencari ilmu, juri dalam pengadilan sehingga berbagai praktisi (Arif, 2017).

Ada berbagai cara untuk mengetahui apakah seseorang telah mengalami pelecehan seksual atau tidak, di mana salah satunya adalah memberikan pertanyaan kepada korban mengenai pengalaman yang telah di alaminya. Dalam pemberian pertanyaan tersebut, korban 
kemudian diberikan daftar perilaku yang dapat dikategorikan sebagai perilaku pelecehan seksual, sehingga kemudian korban dapat menjawab dengan ya atau tidak (Harrits \& Pamungkas, 2015). Hal ini dilakukan karena terdapat adanya definisi yang berbeda mengenai pelecehan seksual bagi korban, sehingga melalui arahan daftar perilaku pelecehan seksual, maka hal ini kemudian dapat mempermudah penentuan atau identifikasi perbuatan pelecehan seksual (Lubis, 2018).

Metode yang banyak digunakan dalam menentukan perilaku pelecehan seksual adalah melalui Sexual Experience Questionnaire (SEQ) yang diciptakan oleh Fitzgerald untuk menghitung pengalaman perempuan dalam menerima perilaku pelecehan seksual dari laki-laki (Tyner \& Clinton, 2010). Dalam daftar pertanyaan ini, Fitzgerald memasukan lima poin penting berupa gender harassement, seductive behaviour, sexual bribery, sexual coercion dan sexual assault atau touching. Jumlah poin dalam menghitung perilaku pelecehan seksual ini berkisar antara 28 hingga 8 . Bergantung kepada konteks yang digunakan, responden sering kali diberikan pertanyaan mengenai indikasi dalam pengalaman pelecehan seksual di dalam domain tertentu (Guschke et al., 2019).

Perbuatan pelecehan seksual dapat mengakibatkan banyak hasil negatif, seperti depresi, gejala PTSD, penurunan kesehatan mental, perasaan isolasi dan ketidakberdayaan, rasa bersalah dan malu atas diri sendiri, sehingga insomnia. Dalam sisi pendidikan, banyak para pelajar yang mengalami efek buruk dari sisi akademik sebagai akibat dari pelecehan seksual seperti berkurangnya kepuasan akademik, persepsi fakultas sehingga berkurangnya performa dalam belajar (Suharyono \& Digdowiseiso, 2021).

\section{METODE}

Penelitian ini dilakukan dengan menggunakan data-data yang diperoleh melalui jurnal, buku atau artikel online yang masih memiliki keterhubungan dan tema yang sama mengenai penelitian ini seperti pelecehan seksual, kekerasan seksual, pelanggaran dalam dunia pendidikan dan sebagainya. Hasil dari data-data yang telah berhasil dikumpulkan ini kemudian dianalisis sesuai dengan tujuan dari fokus penelitian sebagai pedoman, sehingga kemudian dapat menghasilkan kesimpulan yang diharapkan.

\section{HASIL DAN PEMBAHASAN}

\section{Demografi, Prevelansi dan Insiden}

Berdasarkan hasil penelitian-penelitian terdahulu, dapat ditemukan terdapat adanya $19 \%$ murid yang mengalami pelecehan seksual yang dilakukan oleh para staf di perguruan tinggi serta 30\% murid mengaku mengalami pelecehan seksual yang dilakukan oleh teman. Dari para korban pelecehan seksual ini, sejumlah 75,9\% mengalami pelecehan tersebut sebanyak dua hingga tiga kali semenjak belajar di perguruan tinggi. Kemudian setengah dari korban mengalami pelecehan seksual tiga kali dari para pengajar atau staf perguruan tinggi. Sementara itu korban pelecehan seksual yang dilakukan oleh sesama murid, 86,1\% mengalami dua kali pelecehan, sementara setengahnya mengalami enam kali pelecehan seksual sejak belajar di perguruan tinggi.

Berdasarkan pengakuan dari mahasiswa yang masih baru, tingkat pelecehan yang terjadi mencapai $12,5 \%$, sementara bagi mahasiswa senior dapat mencapai $24,9 \%$. Hal ini kemudian menunjukkan bahwa tingkat pelecehan seksual meningkat seiirng waktu yang 
berjalan di perguruan tinggi. Hal ini juga kemudian dapat dilihat bahwa terdapat adanya 28,6\% mahasiswa baru yang mengalami pelecehan seksual di oleh teman sebaya, sementara angka tersebut naik menjadi 35,7\% oleh teman sebaya bagi mahasiswa senior.

Pelaku pelecehan seksual yang berasal dari staf atau pengajar perguruan tinggi terdiri atas $78 \%$ laki-laki, $15 \%$ perempuan, dengan $7 \%$ jenis kelami yang tidak berhasil diketahui oleh korban. Sebanyak 84\% kejadian pelecehan ini terjadi di area perguruan tinggi. Pelaku pelecehan seksual ini berasal dari anggota fakultas sebanyak 61\%, karyawan mahasiswa sebanyak $27 \%$, dan staf sebanyak $12 \%$.

Sementara itu, kasus pelecehan seksual yang dilakukan oleh sesama teman sebagian besar dilakukan oleh pelaku dengan jenis kelamin laki-laki sebanyak 86\%. 11\% diantara pelaku adalah perempuan dan $3 \%$ pelaku tidak berhasil diketahui oleh korban. Jumlah pelaku yang merupakan sarjana adalah 85\%, sementara mahasiswa yang sedang mengambil pascasarjana adalah $15 \%$. Sebagian besar pelecehan seksual yang dilakukan oleh teman sendiri dilaksanakan di dalam perguruan tinggi sebesar $68 \%$.

Melalui perhitungan yang dilaksanakan, waktu memiliki peran yang cukup penting dalam meningkatkan risiko pelecehan seksual kepada korban, di mana bertambahnya peluang berinteraksi dengan pelaku pelecehan seksual akan menambah kemungkinan terjadinya perilaku pelecehan seksual.

Kemudian dapat ditemukan bahwa menjadi perempuan atau gender yang minoritas akan menambah risiko menjadi korban pelecehan seksual. Orang-orang dengan ras mayoritas memiliki risiko lebih kecil untuk menjadi korban pelecehan seksual yang dilakukan oleh staf dan pengajar dari perguruan tinggi dibandingkan ras minoritas. Kemudian umur yang semakin tua ketika memasuki perguruan tinggi juga akan mengurangi risiko menjadi korban pelaku pelecehan seksual.

Hasil-hasil penelitian ini kemudian akan menunjukkan bahwa menjadi perempuan akan dapat meningkatkan terjadinya risiko untuk mengalami pelecehan seksual, namun akan menambah tingkat perilaku yang dialami. Kemudian peningkatan usia ketika melakukan pendaftaran ke perguruan tinggi akan mengurangi risiko terjadinya pelecehan seksual, namun usia yang dimiliki tidak akan memoderasi tingkat perilaku pelecehan seksual.

Melalui hasil penelitian ini ditemukan banyak sekali faktor-faktor yang secara signifikan dapat menambah risiko terjadinya pelecehan seksual oleh teman. Faktor-faktor yang ditemukan tersebut dapat berupa penambahan waktu, menjadi seorang perempuan atau gender minoritas, atau menjadi minoritas seksual, di mana semua hal ini kemudian dapat menambah risiko yang ada. Kemudian menjadi murid non-tradisional atau mahasiswa/i pascasarjana akan mengurangi penurunan risiko pelecehan seksual yang diterima oleh teman.

Penelitian ini memiliki tujuan untuk dapat memprediksi tingkat dan risiko dari pelecehan seksual yang terjadi di lingkungan pendidikan dengan mengidentifikasi melalui kondisi korban. Pelecehan seksual sering terjadi kepada pelajar perempuan, minoritas gender dan jenis kelamin yang menjadi minoritas. Dibandingkan dengan korban lainnya, korban pelecehan seksual dengan kondisi ini mengalami risiko lebih besar sebagai korban dari rekan sejawat dan juga pihak sekolah itu sendiri. Dalam beberapa kasus, pelecehan ini meningkat tajam oleh rekan-rekan sejawat.

Temuan ini kemudian sejalan dengan hasil penelitian yang telah dilakukan oleh Cantor dkk. Waktu yang berjalan selama bersekolah di perguruan tinggi berbanding lurus dengan 
tingkat risiko pelecehan seksual yang diterima oleh korban. Namun terdapat adanya perbedaan dari pelaku pelecehan ini. Kemudian pelajar dengan gender dan jenis kelamin minoritas diprediksi mengalami pertambahan risiko sebagai korban pelecehan seksual, baik oleh rekan ataupun pihak perguruan tinggi. Hasil temuan ini didukung oleh penelitian yang telah dilaksanakan oleh Hill dan Silva. Penelitian yang dilaksanakan mengenai pelecehan kepada pelajar heteroseksual memiliki hubungan dengan depresi, kecemasan, permasalahan penggunaan alkohol, serta menurunkan kondisi kesehatan.

\section{Ras dan Pelecehan Seksual}

Temuan mengenai pelecehan seksual berdasarkan ras atau etnis memiliki sifat yang cukup menarik. Pelajar yang berasal dari ras mayoritas atau cukup dikenal cenderung memiliki risiko yang lebih sedikit untuk menjadi korban pelecehan. Namun kemudian hal ini akan berubah ketika ras minoritas yang menjadi korban. Hasil temuan ini kemudian sejalan dengan penelitian yang telah dilaksanakan oleh Buchanan dan Yoon, bahwa terdapat adanya kenaikan frekuensi risiko pelecehan seksual kepada pelajar yang memiliki ras minoritas.

Walaupun ada beberapa hasil penelitian yang menunjukkan bahwa ras minoritas terkadang tidak menambah risiko sebagai korban pelecehan seksual, namun para pelajar minoritas ini tetap rentan untuk menjadi korban lainnya dalam berbagai kasus. Hal ini dikarenakan terdapat adanya rasisme sosial dan institusional yang terjadi kepada orang-orang minoritas, sehingga kemudian hal ini dapat menyebabkan adanya stereotip, penolakan layanan, pelecehan rasial, suasana yang tidak bersahabat di perguruan tinggi, hingga meningkatkan ketidaknyamanan dan meningkatkan emosi marah.

Hasil temuan-temuan ini kemudian menunjukkan bahwa terdapat adanya potensi yang dapat muncul sebagai akibat dari perbedaan ras dan etnis terhadap pelecehan seksual. Beberapa ahli berpendapat bahwa memisahkan pembahasan mengenai pelecehan seksual dan ras dapat merugikan para penyintas pelecehan seksual sehingga kemudian mempersulit dalam mencari titik-temu.

Hal ini dikarenakan sering kali pelecehan seksual dan rasisme terjadi secara bersamaan, sehingga kemudian mempersulit penghitungan sebagaimana yang telah dilakukan oleh penelitian-penelitian sebelumnya. Wood menyatakan ketika pelajar dengan etnis minoritas mengalami pelecehan seksual, maka terdapat adanya kemungkinan bahwa hal ini akan diikuti oleh tindakan pelecehan rasial yang kemudian dapat menyebabkan PTSD. Sayangnya SEQ yang diciptakan oleh Fitzgerald tidak dapat mengakap adanya perilaku rasial yang masih berhubungan dengan pelecehan seksual yang sering terjadi di dalam perguruan tinggi, sehingga kemudian hal ini menyebabkan terbatasnya pemahaman terhadap pelecehan seksual yang diterima oleh para pelajar dengan ras minoritas.

\section{Waktu Belajar dan Pelecehan Seksual}

Hasil temuan dalam penelitian ini tidak memberikan suatu hal yang baru atau mengejutkan, di mana pelajar sarjana tradisional memiliki risiko tertinggi sebagai korban pelecehan seksual, baik yang dilakukan oleh rekan ataupun yang berasal dari pihak perguruan tinggi. Walaupun begitu, terdapat adanya beberapa penelitian yang memiliki hasil berbeda dengan penelitian ini, di mana mahasiswa/i yang mengambil lulusan yang lebih tinggi memiliki risiko yang juga lebih tinggi sebagai korban pelecehan seksual. Hal ini memang 
memungkinkan untuk dapat terjadi mengingat interaksi yang lebih bertambah serta ketergantungan yang lebih tinggi terhadap perguruan tinggi.

Pelajar yang berada di jalur non-tradisional berada para risiko yang cukup rendah dibandingkan pelajar biasa dalam risiko menjadi korban pelecehan seksual, baik yang dilakukan oleh rekan ataupun pihak perguruan tinggi. Hal ini dapat terjadi karena efek dari paparan yang diterima oleh pelajar non-tradisional bersifat lebih rendah, di mana para pelajar non-tradisional memiliki kesibukan yang berbeda dengan jumlah waktu yang dihabiskan di kampus jauh lebih sedikit.

Walau pelajar yang berusia lebih muda cenderung memiliki risiko yang lebih tinggi sebagai risiko pelecehan seksual, waktu yang dihabiskan di perguruan tinggi juga meningkatkan tingginya risiko pelecehan seksual yang dapat terjadi. Pelajar yang berada di perguruan tinggi lebih lama akan memiliki paparan yang lebih besar juga dengan rekan dan karyawan di perguruan tinggi, sehingga kemudian hal ini akan ikut meningkatkan risiko sebagai korban pelecehan seksual.

\section{Implikasi}

Berbagai permasalahan pelecehan seksual yang terjadi di wilayah perguruan tinggi ini dapat dikurangi melalui berbagai cara. Perguruan tinggi harus dapat mengenali realitas bahwa terdapat adanya perilaku pelecehan seksual yang terjadi kepada murdi-murid mereka, yang kemudian dapat memperburuk potensi akademik serta kesehatan mental. Dengan menangani permasalahan pelecehan seksual di kampus melalui intervensi dan pencegahan, maka perguruan tinggi dapat secara tidak langsung memberikan pesan kepada murid-muridnya mengenai norma gender, ras dan seksual yang sesuai.

Yoon memberikan rekomendasi bahwa perguruan tinggi sebaiknya memberikan perhatian berupa pesan, khususnya mengenai atletik dan maskulinitas, karena kedua hal ini dapat memberikan efek buruk yang secara tidak sengaja terjadi dalam mendukung seksisme dan agresi. Kebijakan-kebijakan yang akan dibuat harus dapat mengatur perilaku pala murid dan staf berdasarkan dengan budaya serta mengakui bahwa identitas yang dimiliki oleh murid dapat mempengaruhi potensi sebagai korban pelecehan seksual. Hal ini dikarenakan risiko akan pelecehan seksual yang dilakukan kepada para staf pengajar dan karyawan yang dilakukan oleh para murid belum dipelajari, sehingga akan menyulitkan upaya intervensi dan pencegahan pelecehan seksual.

Program pencegahan pelecehan seksual yang dilakukan oleh perguruan tinggi dapat mengatasi terjadinya pelecehan seksual melalui integrasi yang sifatnya berkelanjutan yang berasal dari strategi pencegahan pelecehan seksual yang ada, seperti dilakukannya intervensi pengamat. Mengatasi terjadinya seksisme dan gender bias sebagai penyebab utama dari pelecehan seksual dapat menjadi dasar sebagai usaha untuk melakukan pencegahan. Strategi pencegahan dan intervensi dapat menggunakan pendekatan interseksional untuk mengatasi pelecehan seksual dengan memasukkan rasisme dan homofobia ke dalam program.

Berdasarkan laporan yang berasal dari National Academies of Sciences, Engineering and Medicine (NAS) mengenai perilaku pelecehan seksual yang terjadi di dunia pendidikan. Dalam laporannya, NAS memberikan empat rekomendasi yang kemudian dapat memberikan perubahan agar dapat mengakhiri pelecehan seksual, yaitu melakukan integrasi nilai-nilai keragaman dan inklusi ke dalam kebijakan dan prosedur; mengubah dinamika kekuasaan untuk 
dapat meredakan ketergantungan terhadap hubungan penasihat; memberikan dukungan terhadap penyintas pelecehan seksual melalui layanan dan pelaporan yang akan meminimalisir risiko pembalasan dendam oleh pelaku; dan melakukan peningkatan dalam akuntabilitas dan transparasi.

\section{E. KESIMPULAN}

Pelecehan seksual merupakan permasalahan yang cukup sering terjadi di perguruan tinggi dan dialami oleh para murid-muridnya. Hal ini cukup disayangkan karena pengaruhnya yang memberikan dampak negatif, baik kepada korban sebagai individual ataupun bagi kelompok belajar di perguruan tinggi tersebut. Perempuan dan gender minoritas serta mahasiswa tradisional memiliki penambahan risiko dalam pelecehan seksual. Perlu adanya penelitian lebih lanjut untuk dapat melengkapi faktor-faktor identitas dan pengaruhnya kepada risiko pelecehan seksual. Perguruan tinggi juga perlu untuk dapat mempertimbangkan dampak yang diberikan oleh identitas dalam melakukan perencanaan terhadap intervensi dan pencegahan pelecehan seksual di perguruan tinggi. Kemudian perlu adanya perubahan budaya secara mendasar agar dapat mengubah budaya akademik sehingga dapat menghentikan atau setidaknya mengurangi pelecehan seksual yang dapat terjadi di masa depan.

\section{REFERENSI}

Amirudin, N. (2017). Pendidikan Humanisme dalam Perspektif Islam (Konsep dan Implementasinya dalam Pengelolaan Kelas). Jurnal TAMADDUN.

Andini, T. M. (2019). Identifikasi kejadian kekerasan pada anak di Kota Malang. Jurnal Perempuan dan Anak, 2(1), 13-28.

Arif, H. (2017). Rekonstruksi Hukum Tentang Hukuman Kebiri Bagi Pelaku Tindak Pidana Pelecehan Seksual (Kajian Analisis Yuridis-Sosiologis Perppu No. 1 Tahun 2016 Dalam Perspektif Kriminologi Hukum). Khazanah: Jurnal Studi Islam dan Humaniora, 14(1), 110-133.

Bahri, S. (2015). Suatu kajian awal terhadap tingkat pelecehan seksual di aceh. Jurnal pencerahan, $9(1)$.

Digdowiseiso, K. (2020). The Development of Higher Education in Indonesia. International Journal of Scientific \& Technology Research, 9(2).

Efferi, A. (2014). Dinamika Persaingan Antar Lembaga Pendidikan. Quality, 2(1), 96-116.

Guschke, B. L., Busse, K., Khalid, F., Muhr, S. L., \& Just, S. N. (2019). Sexual Harassment in Higher Education-Experiences and Perceptions among Students at a Danish University. Kvinder, Køn \& Forskning, (1-2), 11-30.

Harrits, M. Y., \& Pamungkas, I. N. (2015). Komunikasi Interpersonal Antara Guru Dan Murid Tk Tentang Pendidikan Seks Usia Dini. eProceedings of Management, 2(1).

Hikmah, S. (2017). Mengantisipasi kejahatan seksual terhadap anak melalui pembelajaran "aku anak berani melindungi diri sendiri”: Studi di yayasan al-hikmah Grobogan. Sawwa: Jurnal Studi Gender, 12(2), 187-206.

Kinasih, S. E., \& Dugis, V. M. (2015). Perlindungan Buruh Migran Indonesia Melalui Deteksi Dini HIV/AIDS pada saat reintegrasi ke daerah asal. Masyarakat, Kebudayaan dan Politik, 28(4), 198-210.

Lobodally, A. (2014). Transformasi Simbolik Homoseksual di Televisi (Sebuah Studi Analisis Semiotika Barthes dan Semiotika Sosial MAK Halliday dalam Program CS: File Kompas TV). SEMIOTIKA: Jurnal Komunikasi, 8(1). 
Lubis, S. (2018). Pola Komunikasi Personal Melalui Pendekatan Nilai-Nilai Islami Dalam Upaya Pencegahan Terhadap Perilaku Transgender. Network Media, 1(2).

Mukhlishotin, M. N. (2017). Cyberbullying perspektif Hukum Pidana Islam. Al-Jinayah: Jurnal Hukum Pidana Islam, 3(2), 370-402.

Parma, I. P. G., Ariana, I. N. J., Putri, I. A. T. E., Putra, A. M., Sulistyawati, A. S., Suarka, F. M., ... \& Saharjo, S. J. (2018). Jurnal Perhotelan dan Pariwisata Triatma Jaya JuliDesember 2017. Sekolah Tinggi Pariwisata Triatma Jaya, 7(2), 1-139.

Rahmiana, R. (2019). Komunikasi Intrapersonal dalam Komunikasi Islam. Jurnal Peurawi: Media Kajian Komunikasi Islam, 2(1), 77-90.

Ramadyan, Y. (2010). Pelecehan Seksual (dilihat dari Kacamata Hukum Islam dan KUHP). Retrieved from https://repository.uinjkt.ac.id/dspace/bitstream/123456789/4602/1/YAYAH\%20RAM ADYAN-FSH.pdf

Reitanza, M. A. (2018). Penerapan Konseling Krisis Dengan Pendekatan Terapi Realitas Dalam Menangani Kecemasan Pada Mahasiswa Korban Kekerasan Dalam Pacaran (KDP) (Studi Kasus di Universitas Islam Negeri (UIN) Raden Intan Lampung) Tahun Akademik 2017/2018 (Doctoral Dissertation, UIN Raden Intan Lampung).

Reza, H. (2014). Peran Komisi Perlindungan Anak Indonesia (KPAI) dalam Mengatasi Kekerasan Seksual terhadap Anak. Retrieved from https://repository.uinjkt.ac.id/dspace/handle/123456789/25006

Sihombing, Y. P. (2016). Isu Seksisme Komunikasi Visual dalam Bingkai Semiotika (Studi Kasus pada Iklan United Nation Woman). Jurnal Inovasi, 10(1), 45-58.

Suharyanto, A. (2016). Surat kabar sebagai salah satu media penyampaian informasi politik pada partisipasi politik masyarakat. Jurnal Administrasi Publik: Public Administration Journal, 6(2), 123-136.

Suharyono, S., \& Digdowiseiso, K. (2021). Education and gender wage gap: Evidence from Indonesia. Accounting, 7(1), 33-40.

Sulandjari, R. (2017). Literasi Media Sebagai Pengantisipasi Pelecehan Seksual Pada Anak dan Remaja (Studi Kasus di Kelurahan Pudakpayung Kecamatan Banyumanik Kotamadia Semarang). Majalah Ilmiah Inspiratif, 2(3).

Triana, R. (2018). Internalisisi Jihad Dalam Pendidikan Karater. Edukasi Islami: Jurnal Pendidikan Islam, 7(01), 101-129.

Tyner, L. J., \& Clinton, M. S. (2010). Sexual harassment in the workplace: Are human resource professionals victims?. Journal of Organizational Culture, Communications and Conflict, 14(1), 33.

Wahyudi, W., \& Suyitno, H. (2018). Dampak Perubahan Paradigma Baru Matematika Terhadap Kurikulum dan Pembelajaran Matematika di Indonesia. INOPENDAS: Jurnal Ilmiah Kependidikan, 1(1).

Yuhana, A. N., \& Aminy, F. A. (2019). Optimalisasi peran guru pendidikan agama Islam sebagai konselor dalam mengatasi masalah belajar siswa. Jurnal Penelitian Pendidikan Islam, 7(1), 79-96. 